\title{
CHANGES IN PRODUCTION AND VOLATILES OF FOREIGN TRADE INDUSTRY FRUIT IN POLAND OVER THE YEARS 2010-2017
}

\author{
Maria Rysz, MSc Eng ${ }^{1 *}$ \\ Department of Elementary Sciences, State Higher Vocational School in Krosno \\ *https://orcid.org/0000-0002-9553-4907
}

\begin{abstract}
The purpose of the work was to determine changes in production in Polish foreign trade and the level of fruit that are being consumed by Polish consumers from 2010 to 2017. The article analyses quantitative and valuable changes in export, import and the balance of Polish fruit turnover. The article presents the share of fruit harvest in Poland in the context of global and European production, the importance of Polish fruit export and import, as well as the results of statistical analysis of the impact of fruit supply on the consumption of these products in Polish households from 2010 to 2017. The research shows that the supply of fruit on the Polish market did not have a significant impact on the amount of their consumption in households.
\end{abstract}

Key words: share of fruit, export, import, supply, fruit consumption JEL codes: L66, D12, F14

\section{INTRODUCTION}

The transition from a centrally controlled economy to a market economy and Poland's accession to the European Union had a major impact on changes in Polish fruit-growing. Fruit farming as an important plant production department follows the economic and social changes occurring in the global European and Polish economy. In order to keep up with all changes, Polish fruit-growing is gradually adapting to the changing conditions of farming, and Poland's accession to the structures of the EU has influenced the growth of production and commercial potential on the domestic and foreign market. The level of development of fruit production and its spatial and organizational structure are determined by natural conditions and various socio-economic factors. Fur- ther development of the sector is currently seen in the growth of exports, due to the growing demand for Polish fruit. This is the result of many promotional and informational activities, which are particularly intensified in the situation of the embargo imposed on fruit producers by Russia. For many years, Poland has been the world's largest producer of apples, blackcurrants, raspberries and blueberries, highbush blueberries as well as a significant producer of strawberries. The growth of fruit production is favoured by adequate land resources, a large group of producers, an increase in fruit consumption and the possibility of exporting to new markets (North Africa, Middle East, India, China). Fruit production is an important direction of agricultural production in Poland. An essential element of the planning and organization

${ }^{1}$ Corresponding author: Rynek 1, 38-400 Krosno, Poland, maria.rysz@pwsz.krosno.pl, +48 134375500 
of horticultural production is to learn the trends and changes in fruit consumption.

\section{FACTORS OF PRODUCTION AND ECONOMIC GROWTH IN THE THEORY OF ECONOMICS}

The subject matter of economic factors of the fruit economy is a part of the achievements of the classical and contemporary economic ideas. Production, regardless of the level of socio-economic development, always takes place under conditions of objective limitations (resources of production factors and time).

Theories of economic growth belong to more contemporary phenomena, but the very concept and interest in it, however, dates back to the beginnings of economic thought. In the theory of economic growth among the achievements of the classics of economy one can distinguish, between others, the concept of A. Smith's wealth source, the two-sector model and the theory of comparative costs of D. Ricardo and the theory of economic development of K. Marx. The authors of the first economic doctrines tried to find the answer to the question - what determines the growth of national wealth (currently economic growth) and what kind of factors influence it. The theory of economic growth of the English classical school (Smith, Ricardo, Mill) indicated the greatest importance to two factors of production: labour and capital. Capital was considered the most important (Zadroga, 2016). The classics tried to point to various factors determining the increase in the wealth of nations, and the main emphasis was placed on the size of production. They also claimed that trade is conducive to increasing production and wealth, because by expanding the market it facilitates large-scale specialization and development, and the same time it promotes the introduction of innovation and technical progress in production (Klimiuk, 2016).

Neoclassical theories of economic growth include: Harrod-Domar's growth model, R. Solow's exogenous growth model (Zadroga, 2016), views of the Anglo-American neoclassical school (including A. Marshall), some representatives of the mathematics school and K. Menger from the German historical school (Strzeszewski, 1976). The basic paradigm in the neoclassical theory was one known in the literature of the subject as Harrod-Domar model. On its basis, one can formulate two conclusions, that economic growth is greater and the efficiency of capital is getting greater when the greater part of the national income is spent on investments. Economists, the representatives of the neoclassical, mathematical and classical schools understood the problem of foreign trade, with a starting point of the international specialization problem and the division of global economic resources between different countries (Klimiuk, 2016). A. Marshall introduced the fourth factor of production: organization. In the first half of the twentieth century, this view was strengthened by J.A. Schumpeter, who called it an entrepreneurship. According to him, it had a huge impact not only on the maximization of profit in the enterprise, but also on the functioning of the entire socio-economic system (Glapiński, 2004).

\section{MATERIALS AND METHODS}

The purpose of the work was to determine changes in Polish production, foreign trade and the level of fruit consumption from 2010 to 2017. The work determines the position of Polish production of fresh fruit on the world and EU markets, and its share in global agricultural production. The work also examines the global crop production in Poland. Moreover, the analysis includes export, import, trade balance in foreign trade in fruit and their consumption, as well as the impact of fruit supply volume on the domestic market - the consumption in households calculated using the correlation coefficient. Correlation coefficients were determined using the Person's correlation analysis, which was verified by the Student's - T statistic and Fisher-Snedecor test.

During the work on the production, export, import and fruit consumption issues in Poland, the resources that were used were mainly of secondary nature, such as the Central Statistical Office (Polish acronym GUS) database, analyses and expertise provided by the Institute of Agricultural and Food Economics National Research Institute (Polish acronym IERiGŻ-PIB), as well as other sources. There were also used mathematical and statistical methods in the work. 


\section{THE SHARE OF POLISH FRUIT PRODUCTION IN THE WORLD AND EUROPEAN PRODUCTION FROM 2010 TO 2017}

Fruit farming plays an important role in the food economy complex. Its economic and social importance is determined by the share of horticultural production, trade and agri-food processing in the effects of agriculture as a whole, and especially in the plant production department (Rysz and Szymańska, 2017). The share of fruit in the value of global crop production in 2017 was $11 \%$ and between 2010 and 2017 there was an increase of 2.1 p.p. ( $8.9 \%$ in 2010$)$, and trade plant production accounted for almost 15\% (2017). According to Eurostat data, in 2017 two-thirds of the fruit tree plantation area in the EU was concentrated in Spain, Italy and Poland, and our country had the largest area of apple orchards (Eurostat online database: Agricultural production - orchards).

The importance of fruit growing in Poland is indicated by the size of domestic fruit production against the world and the EU (Table 1).

The data shows that between 2010 and 2017 there was an upward trend in fruit production in the world and in Poland. In the EU, it remained quite stable with slight fluctuations in particular years, which may have resulted primarily from climatic conditions during the growing season. Poland's share in global fruit harvests was quite stable and ranged from 0.4 to $0.6 \%$, and in the EU accounted for $9.9 \%$ on average. The largest share of Poland in the global fruit harvest $(0.6 \%)$ was in 2012-2014 and in 2016. In the EU, in 2012-2015 it remained above $10 \%$, and in 2016 reached the level of $12 \%$.

There is a small number of species of fruit trees, shrubs and perennials in Polish orchards. The fruits of great importance are: apples, plums, cherries, pears, cherries. In the structure of berry fruit production in the country, the most important are strawberries, raspberries, currants (both black and coloured), chokeberry, gooseberry and from 2012 highbush blueberry. In 2010-2017, there was an upward trend in fruit harvest. In 2010, the collections amounted to only 2,733.5 thousand $t$, and in 2017 were higher by $14.8 \%$. Fruit production in Poland has exceeded 4 million t since 2013, except for 2017, when due to unfavourable weather conditions harvests amounted to only 3.2 million $\mathrm{t}$, which constituted about $8.8 \%$ of the production volume in the EU. Harvested by $32.1 \%$ less fruit than the record harvest in 2016. Smaller than last year were apple harvests $(32.3 \%)$, pears $(32.4 \%)$, plums $(46.7 \%)$, cherries $(63.2 \%)$, raspberries (19.1\%), strawberries $(9.7 \%)$, currants (22.5) and gooseberries (24\%). The decline in the production of most fruit in the country was caused by unfavourable weather conditions for horticultural

Table 1. Worldwide, European and Polish fruit production, Poland's share in world and EU production between 2010 and 2017

\begin{tabular}{|c|c|c|c|c|c|}
\hline \multirow{2}{*}{ Year } & \multicolumn{3}{|c|}{ Fruit production (million $\mathrm{t})$} & Polish share in the world & $\begin{array}{c}\text { Polish share in the UE } \\
(\%)\end{array}$ \\
\cline { 2 - 4 } & world & EU & Poland & 0.4 & 7.5 \\
\hline 2010 & 613.9 & 36.8 & 2.7 & 0.5 & 8.8 \\
\hline 2011 & 637.6 & 38.8 & 3.4 & 0.6 & 10.5 \\
\hline 2012 & 636.5 & 36.5 & 3.8 & 0.6 & 10.9 \\
\hline 2013 & 676.7 & 38.0 & 4.1 & 0.6 & 10.7 \\
\hline 2014 & 689.9 & 39.3 & 4.2 & 0.5 & 10.4 \\
\hline 2015 & 854.0 & 39.0 & 4.0 & 0.6 & 11.8 \\
\hline 2016 & 717.7 & 38.8 & 4.6 & 0.4 & 8.8 \\
\hline 2017 & 865.6 & 37.0 & 3.2 & & \\
\hline
\end{tabular}

Source: own calculations based on: the GUS "Statistical Yearbooks of Agriculture" for the period of 2011-2018 - information about world and Poland; the IERiGŻ-PIB journal "Fruit and vegetable market - status and prospects. Market analysis" No 49/2016 for the period of 2010-2012 and No 53/2018 for the period of 2012-2017 - information about the EU. 
crops during their flowering period, the trees and fruit shrubs suffered the most as a result of strong frosts in early May, which significantly limited or even prevented yielding. Some fruit also suffered as a result of summer hail. The increase in fruit production between 2010 and 2017 could be affected both by relatively high land resources and a large group of enterprising producers with a high level of professional and marketing knowledge and the possibility of using national and EU subsidies. The well-developed base of the domestic processing industry is very important in the development of the production of berries. According to the latest orchard survey in Poland, carried out in 2017, fruit growing is still developing. More and more expenditure is spent to fruit production and storage. From year to year there is an increasing concentration and specialization of fruit production, the production potential of orchards also increases, especially apple orchards (GUS, 2018).

\section{EXPORT, IMPORT AND BALANCE OF TURNOVER OF FRESH FRUIT BETWEEN YEARS 2010 AND 2017}

An important factor that stimulates the development of domestic fruit production is their export. Although the share of fruit in total Polish exports is not high, due to the number of farms involved in this type of production and the significant position of Poland in the global export of some fruit groups (e.g. apples), it is worth analysing how Polish exports, imports and the fruit turnover balance were changing. The changes (quantitative and value fluctuations) of Polish exports, imports and the balance of fruit turnover between 2010 and 2017 are presented in Table 2.

In 2010, Poland sold 921.6 thousand t of fruit worth almost 365.1 million EUR, and in 2017 the country exported almost 1.5 times more (1,291.4 thousand $\mathrm{t}$ ) with a total value of 624.5 million EUR (an increase of $41.5 \%$ on a quantitative basis and $71 \%$ in terms of value). The analysis of Polish export of fresh fruit shows that there was a positive trend regarding its quantity and value. In the analysed period there was also a quantitative increase in fruit imports to Poland from $1,117.1$ thousand to $1,741.9$ thousand $\mathrm{t}(46.7 \%)$ and valuable from 842.6 million to $1,539.6$ million EUR (82.7\%). Despite the increase in exports in the majority of analysed years, the negative balance of foreign trade in fruit was maintained and amounted to -450.5 thousand $\mathrm{t}(-915.1$ million) in 2017 . In quantitative terms, it was $64.1 \%$, and its value was $91.6 \%$ higher than in 2010.

In four of the analysed years $(2011,2014,2015$ and 2017) there was a quantitative decline in fruit exports. In 2011 and 2017, this was due to lower fruit harvest in Poland caused by bad weather conditions during the growing season. On the other hand, the years from 2014 to 2017 are the period of the Russian embargo on plant products (including fresh fruits) originating from the $\mathrm{EU}$, which significantly affected

Table 2. Export, import, balance of turnover of fresh fruit in Poland in 2010-2017

\begin{tabular}{|c|c|c|c|c|c|c|}
\hline \multirow{2}{*}{ Year } & Export & Import & Balance & Export & Import & Balance \\
\cline { 2 - 7 } & \multicolumn{3}{|c|}{ thousand t } & \multicolumn{3}{|c|}{ million EUR } \\
\hline 2010 & 912.6 & 1187.1 & -274.5 & 365.1 & 842.6 & -477.5 \\
\hline 2011 & 776.4 & 1252.8 & -476.4 & 396.4 & 870.2 & -473.8 \\
\hline 2012 & 1263.9 & 1242.2 & 21.7 & 621.9 & 900.4 & -278.5 \\
\hline 2013 & 1515.3 & 1344.7 & 170.6 & 727.9 & 1032.9 & -305.0 \\
\hline 2014 & 1370.3 & 1400.0 & -29.7 & 612.8 & 1110.7 & -497.9 \\
\hline 2015 & 1175.5 & 1458.8 & -283.3 & 567.4 & 1217.3 & -649.9 \\
\hline 2016 & 1366.3 & 1503.5 & -137.2 & 592.3 & 1282.5 & -690.2 \\
\hline 2017 & 1291.4 & 1741.9 & -450.5 & 624.5 & 1539.6 & -915.1 \\
\hline
\end{tabular}

Source: own study based on data from the IERiGŻ-PIB journal "Fruit and vegetable market - status and prospects. Market analysis" Nos 39/2011, 43/2013, 47/2015, 51/2017 and 53/2018. 
the size and directions of exports from Poland, especially apples. In 2014 and 2015, there was a significant quantitative decline in their exports when compared to the previous year, respectively by $9.6 \%$ and $14.2 \%$. The increase in volume and value of the balance in foreign trade in fruit in 2016 compared to the previous year was primarily the result of increased exports of apples, especially to the countries of the Eurasian Economic Union (a double increase in the value of apple exports to Belarus when compared to 2015 - GUS, 2017), the Middle East and China.

The rich use of EU and national support funds for the horticultural sector has contributed to the growth of Polish fruit exports in terms of quantity and value. The funds were mainly directed to the building of modern cold stores, which allowed to increase the flexibility in adapting supply to the structure and seasonality of the demand of sales markets. This factor, in connection with the increased concentration of fruit supply, made it possible for Poland to use the main advantage of domestic products in relation to other major exporters in the world, i.e. relatively low prices in the export offer (Nosecka, 2014).

\section{THE IMPACT OF FRUIT SUPPLY ON THE DOMESTIC MARKET BETWEEN 2010 AND 2017 FOR THEIR CONSUMPTION}

The economic growth of the country, and thus also the increase in the income of the population, contributes to the change in the structure of consump- tion of fruit by consumers. In the civilized countries, the level of fruit consumption is considered as an exponent of the living standard of society. The measure of the consumption level is no longer the quantity, the assortment structure, the distribution of intake during the day and the quality of the consumed fruit become more important (Olewnicki, 2010). Public awareness of the impact of fruits on human health in the $21^{\text {st }}$ century is one of the main factors that determines their intake in humans. This is confirmed by research, among others Jasiulewicz (2011), Włodarczyk and Adamowicz (2011), Stolarska (2014) and Strojewska (2017). In recent years, there has been a worldwide increase in the consumption of fresh fruit, which may, first of all, result from the concern of consumers for a well-balanced diet, appreciation of the dietary values of these products and increased consumption of salads, juices and fruit drinks.

Based on the analysis, it was found that between 2010 and 2017 fruit production was growing (Table 1). A similar situation occurred in the case of fruit consumption (Table 3).

According to data from 2010 to 2017 , there was an increase in fruit consumption by $20.5 \%$. In 2011, 2013 and 2017, a slight decrease in their consumption was observed in relation to the previous year, which could have resulted from lower harvests in those years, and thus higher fruit prices on the market. In the analysed period in foreign trade, both exports and imports showed an upward trend (Table 2). On the

Table 3. Fruit consumption and supply on the domestic market in 2010-2017

\begin{tabular}{|c|c|c|}
\hline Year & $\begin{array}{c}\text { Fruit consumption } \\
\text { (kg per person) }\end{array}$ & $\begin{array}{c}\text { Fruit supply } \\
\text { (thousand } \mathrm{t})\end{array}$ \\
\hline 2010 & 44 & 3018.0 \\
\hline 2011 & 42 & 3891.0 \\
\hline 2012 & 46 & 3821.5 \\
\hline 2013 & 46 & 3957.7 \\
\hline 2014 & 47 & 4218.0 \\
\hline 2015 & 53 & 4332.2 \\
\hline 2016 & 54 & 4780.9 \\
\hline 2017 & 53 & 3601.5 \\
\hline
\end{tabular}

Source: own study based on the GUS and the IERiGŻ-PIB data. 
basis of the analyses carried out at work, it was assumed that the annual level of fruit consumption in households depends on the harvest and import of fruit in a given year, reduced by the volume of exports, i.e. from the so-called fruit supply on the domestic market.

The article attempts to determine whether between 2010 and 2017 there was a linear relationship between the supply of fruit on the domestic market and the amount of consumption per year per one person in the household. In the analysed period, the factor that could have influenced the level of fruit consumption was the price. Due to the access to collective data regarding the general supply of fruit on the market and consumption, the role of the price in the development of the indicated dependence was not taken into account.

The Pearson correlation coefficient for variables referring to the supply of fruit on the domestic market and annual fruit consumption per one person in a household amounted $r=0.55$. On this basis, a moderate positive correlation was found between the supply of fruit on the domestic market and its consumption between 2010 and 2017 .

Based on the additional verification of the significance of the correlation coefficient, it can be concluded that the supply of fruit on the domestic market had no impact on the consumption of fruit in households between 2010 and 2017. It can be assumed that the increase or decrease in the supply of fruit products in a given year did not have a significant impact on the volume of their consumption in Poland. Changes in fruit consumption in the analysed period may have been conditioned by other factors, such as the price or change in eating habits, recommendations of global health organizations and numerous campaigns promoting fruit consumption in Poland.

\section{SUMMARY}

For many years, Poland has been among the world's and European leaders in fruit production. Fruit production in the world, the EU and Poland between 2010 and 2017 has increased. The structure of fresh fruit production is dominated by apples, cherries, strawberries and currants. In 2015, a decline in crops was recorded due to weather conditions and the Russian embargo, and in 2017 a significant decrease in harvest was due to the very low yield of individual fruit species as a result of spring frosts and hail during the summer. In foreign trade, both exports and fruit imports showed an upward trend. Between 2012 and 2017, export and import of fruit from and to Poland exceeded 1 million $t$. The value of exports increased over 600 million EUR (except for 2015), and import by 900 million EUR. In most of the analysed period, in terms of quantity, imports of fresh fruit exceeded their exports. Based on the increase in fruit consumption between 2010 and 2017, it can be concluded that Polish consumers appreciate the nutritional value of fruit, the opinions of doctors and dieticians about their beneficial effects on health and physical condition. However, there is no link between their supply on the market.

\section{REFERENCES}

1. Eurostat: Agricultural production - orchards. Retrieved from: https://ec.europa.eu/eurostat/statistics-explained/ index.php/Agricultural_production_-_orchards [Access 11.04.2019].

2. Glapiński, A. (2004). Kapitalizm, demokracja i kryzys państwa podatków. Wokół teorii Josepha Aloisa Schumpetera [Capitalism, Democracy and the Crisis of Tax State: Around Schumpeter's Theory]. Oficyna Wydawnicza SGH, Warszawa.

3. GUS (2017). Wyniki produkcji roślinnej 2017 [Crop production in 2017]. Warszawa.

4. GUS (2018). Produkcja ogrodnicza. Badanie sadów w 2017 roku [Gardening production. Examination of orchards in 2017]. Warszawa.

5. Jasiulewicz, A. (2011). Rozpoznanie motywów i bariery konsumpcji owoców i produktów owocowych na podstawie rezultatów badań jakościowych [Diagnosis of motives and barriers of fruit and fruit products consumption on the basis of quality survey results]. In: M. Adamowicz (ed.) Konsumenci a innowacje na rynku owoców [Consuments and innovations on fruit market]. Wydawnictwo SGGW, Warszawa, pp. 51-61.

6. Klimiuk, Z. (2016). Ewolucja tradycyjnych koncepcji handlu zagranicznego w teorii ekonomii [The evolution of traditional concepts of foreign trade in the economic theory]. Zeszyty Naukowe PWSZ w Płocku, Nauki Ekonomiczne, 24, pp. 7-25. 
7. Nosecka, B. (2014). Konkurencyjność zewnętrzna świeżych owoców i warzyw z Polski. [External Competitiveness of Fresh Fruits and Vegetables from Poland]. Roczniki Naukowe SERiA, 16(4), pp. 213-218.

8. Olewnicki, D. (2010). Przemiany wybranych czynników ekonomicznych gospodarki sadowniczej i warzywniczej w gospodarce żywnościowej w latach 1980 -2008 [Changes in selected economic factors of fruit and vegetable production in the food sector of the Polish economy in the years 1980-2008]. Zeszyty Naukowe Instytutu Sadownictwa i Kwiaciarstwa im. Szczepana Pieniążka, 18, pp. 167-180.

9. Roczniki Statystyczne Rolnictwa. Lata 2011-2018 [Statistical Yearbooks of Agriculture. Period of 2011-2018]. GUS, Warszawa.

10. Rynek owoców i warzyw - stan i perspektywy. Analizy rynkowe [Fruit and vegetable market - status and prospects. Market analysis], 39/2011; 43/2013; 47/2015; 51/2017; 53/2018. IERiGŻ-PIB, Warszawa.

11. Rysz, M., Szymańska, J. (2017). Zmiany na rynku owoców w Polsce w latach 2010-2015. [Polish fruit market in 2010-2015 trends and changes]. Zeszyty Naukowe WSES w Ostrołęce, 1 (24), pp. 155-166.

12. Stolarska, A. (2014). Demand of Polish households for fruit as an opportunity for the development of domestic fruit production. Acta Scientiarum Polonorum. Oeconomia, 13 (4), pp. 157-167.

13. Strojewska, I. (2017). Polski i światowy rynek wybranych owoców, warzyw i ich przetworów [Polish and world market of selected fruits, vegetables and their preserves]. Monografie Programu Wieloletniego 2015-2019, 66. IERiGŻ-PIB, Warszawa.

14. Strzeszewski, Cz. (1976). Integralny rozwój gospodarczy [Integral economic development]. ODiSS, Warszawa.

15. Włodarczyk, A., Adamowicz, M. (2011). Czynniki kształtujące konsumpcję owoców i przetworów owocowych w Polsce w latach 1990-2007 [Factors influencing consumption of fruits and fruit products in Poland in year 1990-2007]. In: M. Adamowicz (ed.) Konsumenci a innowacje na rynku owoców [Consuments and innovations on fruit market]. Wydawnictwo SGGW, Warszawa, pp. 38-50

16. Zadroga, A. (2016). Ewolucja teorii ekonomii rozwoju w XX wieku: od kategorii wzrostu gospodarczego do koncepcji zrównoważonego rozwoju [Evolution of the theory of development economics in $20^{\text {th }}$ century: from economic growth to sustainable development]. Kwartalnik Kolegium Ekonomiczno-Społecznego Studia i Prace, 2, pp. 117-135. 